\title{
Mad, terroir og tv: Smag på Danmark!
}

\section{Af Dorthe Refslund Christensen og Karen Klitgaard Povlsen}

Mad fylder mere i medierne, men hvordan underholder fx et madprogram på tv? Med afsæt i de 13 afsnit af Claus Meyer-serien Smag på Danmark! ${ }^{1}$ undersøger vi, hvordan serien er konstrueret og fortalt. Især ser vi på, hvilken rolle de 13 forskellige steder, som serien foregår på, har. Vi diskuterer begreber som terroir og mytologisering. Serien etablerer dobbeltheder og relationer, og i tråd med dette forlenes sted som terroir både med al og med ingen betydning.

Mad knyttes som et tegn, med Barthes in mente, til stedet, men på en måde, der leverer rum for seerens eget forestillingsarbejde. Serien demonstrerer for seerne, hvordan smagsdomme kan foregå med Meyer som seerens stedfortræder i et ferie- og fritidsunivers. Den nydelse, som serien konstant etablerer, demonstrerer og anticiperer, kan seeren deltage i med sit eget fantasiarbejde: Det er god underholdning, fordi så meget er overladt til seernes forestillingsarbejde.

Claus Meyer demonstrerer på tv-skærmen, hvordan "du" laver lammefarspølser. Kameraet fokuserer i et ultranært perspektiv på de hænder, der pakker fars ind i fedthinde og steger dem på en pande. I halvtotal ser vi derefter Claus Meyer lægge lammepølsen på bordet, i ultra-close-up skærer han den igennem, og i halvtotal fører han pølsebidden til munden. Bag ham ser vi himmel og marsklandskab i solblæst med spredte făr foran diget 15 meter fra den tyske grænse. Han tygger eftertænksomt, kameraet hviler i tæt close-up på hans ansigt. "Det smager ikke godt..." siger han - og griner så: "jo, den smager godt!" (Afsnit 10: DR: 10.07.07 Sønderjylland). ${ }^{2}$

\section{Mad i medier}

Det er vanskeligt at få et overblik over, hvor meget maden fylder i medierne. Men det er let at se, at udbuddet af medie-mad er blevet større. Vi ser flere magasiner med mad, flere avistillæg om mad, mere nyhedsstof om mad og mere mad på tv, ${ }^{3}$ både som egentlige madprogrammer og som indslag i andre programmer, fx de magasinprogrammer, der dækker dele af morgenfladen og den tidlige aftenflade.

Vores interesse i denne artikel er at se på, hvordan et madprogram kan fungere på tv, fx til forskel fra de trykte medier. Vi vil i det følgende tage udgangspunkt i serien New Scandinavian Cooking, på dansk: Mad i Norden, med 13 programmer med madentrepreneuren Claus Meyer, og se på, hvordan programmerne fungerer som tv, hvordan de fremtræder for seerne, og hvad stedet, det særligt skandinaviske og især det særligt danske, betyder for serien. Tv har særlige muligheder for at præsentere handlinger i en scenografi, der bliver ensbetydende med et sted, der forankres af de mennesker, seeren 
ser på stedet eller i scenografien. Vi vil altså undersøge, hvad det betyder, at Claus Meyer er med et transportabelt køkken bestemte steder i Danmark, hvor han bl.a. møder andre mennesker - som en potentiel stedfortræder for seerne. For at gøre det vil vi inddrage teorier om mytologisering og terroir. Vi opfatter serien som et forsøg på at eliminere traditionelle dikotomier ( $\mathrm{fx}$ natur-kultur, lokal-global, viden-sansning) og etablere sammensatte relationer mellem dem på en måde, der er særegen for tv, og som måske er anderledes end det, vi ser på tryk eller på nettet. Vi ser serien med en forestilling om, at forbruget af medier kan være med til at stimulere forestillingsevnen og opnå en nydelse i fantasien, som ikke nødvendigvis udløses i faktisk forbrug (Jantzen, 2007, p. 83-85). Med den pointe, at selve medieforbruget faktisk allerede er et forbrug.

\section{Mad på tv}

Madopskriften og med den en eller anden form for 'ekspert'-råd om madlavning og smagskompetence er gængs mediestof og er ikke i sig selv noget nyt. DR udvikler løbende nye madprogrammer, men da et program, der var planlagt i et primetime-slot, blev forsinket i 2007, valgte man (billigt!) at købe en serie produceret af det norsk-amerikanske produktionsselskab Tellus Works. ${ }^{4}$ Man viste de 13 episoder på DR1 fra 8. maj-31. juli 2007 i tidsrummet 20.30-21 hverdagsaftener henover sommeren - og genudsendte dem på samme tidspunkt sommeren 2008. På trods af, at sommeren er lavsæson for tv, fik serien pæne seertal: Mellem 10 og 15 procent af befolkningen fulgte serien (ca. 600.000), lidt flere kvinder end mænd og med en lidt overproportional andel af mellem- og langtuddannede (Gallup TV-Meter-kørsel 2. halvår 2007) i forhold til befolkningssammensætningen. Serien var altså en pæn succes, men hvorfor? Fordi det faktisk var ferieegnet tv? Fordi det var underholdende tv? Eller fordi Claus Meyer er et kendt navn, der signalerer god smag og madkvalitet? Det skal vi ikke svare på her, men vi skal se på seriens måde at præsentere madlavning i tv, på nettet og i bogform. Hvorfor er mad på tv så underholdende, at det kan tiltrække seere hen over en sommer, som traditionelt er lavsæson?

Roland Barthes konstaterede i 1969, at 1960'erne viste "an extraordinary expansion of the areas associated with food":

Today, we might say all of them: activity, work, sports, effort, leisure, celebration - every one of these situations is expressed through food. We might almost say that this 'polysemia' of food characterizes modernity: in the past only festive occasions were signalized by food in any positive and organized manner. But today, work also has its own kind of food (on the level of a sign, that is): energy-giving and light food is experienced as the very sign of, rather than only a help toward, participation in modern life (Barthes, 1979, p. 167).

Maden er i sig selv et udtryk for at være moderne, for det at deltage i det moderne hverdagsliv med arbejde, sport og fritid. Mediernes madstof viser, hvordan man kan bruge maden som tegn, og hvilke former for mad der kan bruges som tegn på hvilke felter: arbejde, fritid osv. Mad i Norden fokuserer på fritiden. Danmark præsenteres som et fritids- og feriested, ligesom maden, der vises, er fritidsmad, ikke sportsmad eller arbejdets kantinemad. Madens stedslige tilknytning til feriesteder understreges og den mad, der tilberedes, tilberedes til en nydelse, der normalt ikke har hjemme i hverdagens eller arbejdslivets travle rum. Her går det langsomt, her laver man mad og spiser den 
uden for i den lokale natur. Så overordnet kan man sige, at de tegnværdier, som mediet her understreger i maden, er værdier, der forbindes med fritid, og som derfor signalerer fritid, fri-hed.

Et af de felter, maden ekspanderede på i 1960'erne i Danmark, var medierne. De nye livsstilsmagasiner som Bo Bedre (1961-) viste mad i hidtil uhørt store billeder og opsætninger (Klitgaard Povlsen 1986 og 1997, p. 270-75), samtidig med at dameugebladene udvidede deres madreportager. Den ekspansion er fortsat frem til i dag i de trykte medier, inklusive kogebøger.

På tv begyndte maden ifølge Ulrik Boesens TV-Køkkenet (2000) i 1965 med Norma Bøgedals Lørdagsmagasinet. Her blev kokkeparret Conrad Bjerre-Christensen og Aksel Larsen introduceret, og da de blev populære, producerede Norma Bøgedal derefter aftenprogrammet TV-Køkkenet med de to. Det fortsatte frem til Conrad Bjerre-Christensens død i 1976, dog med flere afbrydelser undervejs, hvor de kvindelige kokke Grete Grumme og Lotte Havemann kom til i 1970'erne sammen med Roy og Jan Hurtigkarl (1969-83). Erwin Lauterbach og Hans Beck Thomsen kom til i 1980'erne og 1990'erne. De var alle kendte kokke og kendte madskribenter fra de trykte medier og kogebogsmarkedet. Ekspansionen er fortsat på tv op til i dag med kokke som Anne Larsen, Kille Enna, Claus Meyer - og de udenlandske som fx Jamie Oliver, Tina Nordström og Nigella Lawson, og ekspansionen på tv fungerer tæt sammen med en tilsvarende ekspansion på tryk - i bøger og blade - og på nettet. ${ }^{5}$

Tv-køkkenet var fra begyndelsen lagt didaktisk an og introducerede danskerne til det franske køkkens smagsværdier med dets fokus på råvaren og skånsomme tilberedninger som sautering og braisering. Der er stadig et stort element af belæring i madprogrammerne, men i dag ligger vægten ofte lige så meget på information om råvaren som tilberedningen af den. De fleste af de tv-kokke, der optræder på de danske tv-kanaler i dag, er stadig kendte madskribenter, der først er kommet til orde i de trykte medier, tag fx Adam og James Price og Nicolaj Kirk. Men tv sætter andre rammer for formidling end trykte medier gør, hvor det skrevne ord står i centrum suppleret med få billeder af den færdige ret.

Barthes analyserede det sæt af værdier, der knyttedes til mad i de trykte medier i 1970'erne:

.... whole set of ambiguous values of somatic as well as psychic nature, clustering around the concept of health. In a mythical way health is indeed a simple relay midway between the body and the mind; it is the alibi food gives to itself in order to signify materially a pattern of immaterial realities (Barthes, 1979, p. 169).

Barthes fandt en ny ernæringsbevidsthed, "food is thought out" skriver han, ikke bare af specialister "but by the entire public" (ibid.). Sundhedsforestillinger kan antage mangfoldige former, og det er i dag en tendens, at sundheden formuleres i forhold til råvaren (og dermed stedet) mere end i forhold til den krop, der skal indtage føden. Vi kan tale om en senmoderne vitalisme knyttet til jorden/naturen, men medieret af maden på tv. Det er netop dette forestillingsfelt mellem kroppen og hjernen via mediet, som moderne tv-serier som Mad i Norden demonstrerer med Claus Meyer som guide. Mens fantasien tidligere blev aktiveret af didaktik om ernæring og funktionel tilberedning og af måltidets socialitet som mål, er forestillingsfeltet i dag snarere knyttet til sted, smag og nydelse. Vi fokuserer her på to former af forestillinger: maden som udtryk for en situation (fritid) og maden som formidler af et sted, men det er et valg blandt flere muligheder. Begge 
forestillinger kan ses som en form for mytologisering i Barthes' forstand, nemlig som en selvfølgeliggørelse af maden som tegn og af dette madtegns betydningsmuligheder.

Vi ser serien som udtryk for en international tendens. Frances Bonner (Bonner, 2005, p. 35-46) har vist, hvordan maden på australsk tv har allieret sig med livsstilsprogrammer og har bredt sig på tv-fladen i og uden for prime time. Hun ser en generel udvikling væk fra det didaktiske tv med fokus på hændernes håndtering af maden og iagttager flere closeups på kokkenes ansigter, der giver udtryk for henført nydelse af smagen. Kun få kokke i hendes materiale agerer som formidlere mellem forskellige køkkener og steder i verden - de agerer derimod som repræsentanter for de forskellige steder og etniske køkkener. Toby Miller (Miller, 2007, p. 112-143) fokuserer derimod på flermedialitet i forskellige tvkokkes optræden og kritiserer, at fokus på opskriften forstærkes, mens maden som bredere kulturelt, socialt og miljømæssigt felt tenderer mod at forsvinde. Netop flermedialiteten ser vi som en af årsagerne til, at fokus på opskriften forstærkes. Det er let at mediere en opskrift i flere medier, typisk på tv, internet og på tryk. Det er straks sværere at anlægge et bredere perspektiv og bruge samme materiale i diverse medier. Netop et fokus på stedet, på terroir og autenticitet er en oplagt mulighed for både at arbejde flermedialt og at udnytte mediernes særtræk, som det australske eksempel også viser (Bonner, 2005). Både tv, kogebøger, netportaler og magasiner fokuserer i satsningen på det nye skandinaviske køkken på stedet og dets autenticitet, men de må gøre det forskelligt, da de har forskellige muligheder for at mediere madstederne autentisk.

\section{Claus Meyer i Limfjorden og på Læsø}

Mad i Nordens danske dele består i alt af 13 danske udsendelser med Claus Meyer som vært. 11 episoder viser rundt i Danmark, en på Grønland og en i Norge. Alle 13 episoders intro er ens og består af underlægningsmusik med en serie Danmarksbilleder, tre ad gangen på skærmen ni gange. Tiende gang samler billedet sig til ét billede. Billedforløbet viser skiftevis dansk natur i totalbilleder eller close-ups, Claus Meyer i halvtotal eller close-up og mad i close-up eller ultra-close-up. Underlægningsmusikken er enkel og klar i klangen med en dynamisk og dog let nostalgisk tone, bl.a. i temaer, som lyder bekendte uden helt at være det. Men en tydelig studielyd og brug af digitale klange gør samtidig musikken flad, tynd og kunstig i forhold til scenografien, mens reallydene er anderledes påtrængende og har mere fylde. Der er sommerlys på alle billeder, der har reklamefotoets renhed og klarhed, men lyssætningen på Claus Meyer er iøjnefaldende kunstig i forhold til stedets naturlige lyssætning.

Det første afsnit (Afsnit 1: DR: 08.05.07) viser en lille lyseblå kutter i aftensol sejle på kanalen ind til Løgstør og hen mod kameraet - i et forår med 'nordisk' saxofon som underlægningsmusik. I næste klip er kameraet med på kutterens forstavn, klip igen og kameraet viser Claus Meyer i halvtotal stå på kutteren og henvende sig direkte til seerne: "Hej og velkommen til muslingebyen Løgstør...". I skift mellem klip af Claus Meyer på en kutter og lækre hav-med-nedadgående-sol-billeder præsenterer Claus Meyer de madretter, programmet vil vise tilberedningen af, korte klip med close-ups af maden afbryder natursceneriernes heltotaler - og et kort over Limfjorden med rød ring om Løgstør. Efter præsentationen fortælles, at limfjordsøstersen har en særlig markant smag i modsætning til sydligere østers pga. det kolde vand i Limfjorden. Som en forankring af den påstand toner afsnittets overskrift frem på skærmbilledet: "Den særlige Limfjordssmag." Introen viser programmets elementer: lige dele natur, Claus Meyer og mad. Lige dele panoramiske totalbilleder af naturen, halvtotaler og close-ups af Claus Meyer og tætte close-ups af 
maden med og uden Claus Meyers hænder og fingre. Fotograferingen betyder sammen med den påtrængende underlægningsmusik, at der skabes en dynamisk stemning i programmet, samtidig med, at der er mange close-ups og dvælende naturbetragtninger: Dobbeltheden er således en gennemgående struktur i programmet i forhold til både form og indhold.

I næste klip ser vi Claus Meyer stå ved sit mobile køkkenbord på kajen ved kanalen. Først laver han en dressing, kameraet fokuserer mest på hans hænder, men med hav og både ved kajen som pittoresk baggrund. Meyer fortæller om garniture til østers og laver en dressing med æbleeddike (Meyers egen produktion), æbler (egen produktion?) og rapsolie (dansk). Kameraet følger ingredienserne og kniven i æblet. Men da Claus Meyer henvender sig direkte til seerne: "Og det er vigtigt, at du skærer æblet i fine tern", er det med close-up på hans ansigt, mens lyden af hakkende kniv fortsætter. Derefter dvæler kameraet i et ultra-close-up på de fine æbletern, der 'suger' dressingen ind. Da Meyer stikker en ske i den færdige dressing og fører den til munden, følger kameraet skeen, og der etableres en vis suspense, mens Meyer med indadvendt blik tygger og så smager på sin dressing med lukkede øjne. Henført konstaterer han: "Mmm, det smager skønt. Det river lidt, men når først det møder østerskødet så bliver det rigtig godt." Sekvensen er et mønstereksempel på, hvordan tilberedningen af maden foregår: Vi får lidt fakta-viden om råvaren og stedets betydning for smagen, vi vises, hvordan de autentiske råvarer ser ud, og kameraet følger dvælende råvarer og tilberedning og kokkens hænder, afbrudt af kokkens direkte tale til kameraet og endelig clouet i hver sekvens: smagningen. Seerne kan naturligvis ikke smage, men pointen i den analyserede sekvens er netop også, at det kan Claus Meyer heller ikke: Han smager på dressingen, men kun for at forestille sig, hvordan den vil smage i mødet med en østers. Der finder altså en flerleddet demonstration sted her: For det første kan seerne med kameraets hjælp forestille sig limfjordsnaturen. For det andet får vi en belæring om råvarens smagskvalitet, hvor læren er, at stedet og klimaet er afgørende for kvaliteten, vi belæres i kælne billeder om håndteringen af råvaren, og endelig kan vi med billedet og tekstens forankring forestille os smagskvaliteten, som vi oplever pr. stedfortræder, nemlig Claus Meyer, der skærer utrolig langsomt og dermed didaktisk af en professionel at være. Muslingerne serveres til sidst for to lokale (anonyme) fiskere, men der dvæles ikke ved deres smagning eller ved den sociale oplevelse af måltidet. Det er ikke måltidet, der er i centrum, det er smagsforventningen i optakten til måltidet, der er centrum for fortællingen. Madens sociale funktion er således næsten helt fraværende i programmet, det er madens stedsforankrende funktion, der er i centrum og dermed mad som branding af et sted og dette steds råvarer. Serien er kommercielt produceret, men vises på en public service-kanal, der kan antages at øge troværdigheden af brandingen, især fordi kokken Meyer er en kendt tv-kok netop fra denne kanal.

Programmet er opbygget sekventielt. Der er reportager fra fiskeriet og fra fabrikken i Vildsund, hvor østers pakkes, der er bordscener, hvor Claus Meyer tilbereder maden med mange close-ups på hakning og tilskæring, der foregår usædvanligt langsomt. Fjorden er til stede i de fleste billeder, Claus Meyers bord er placeret med vandudsigt i langt de fleste afsnit. Kun i reportagedelene, her også fra muslingefestivalen i Løgstør i begyndelsen af april, er havet ikke med på billederne, men erstattes så af folkeliv eller fabriksliv: Vi forankres som seere uafbrudt i stedet. Bordet, Claus Meyer laver mad på, er eksklusivt, men enkelt, men der er altid krydderurter, olie og grøntsager. En særlig rolle spiller eddikerne - fra Claus Meyers produktion. Det nævnes aldrig, men flaskerne er umiskendelige. Olien, der bruges, er altid rapsolie, i afsnittet om Læsø (Afsnit 7: DR: 
19.06.07) får vi at vide, at olivenolie er godt, men unordisk. Redskaberne er Eva-Triogryder, Le Creuset-kander og -gryder, Holmegård-skåle, Royal Copenhagen-tallerkener, keramik- og glasunika. Produktplaceringen er diskret, men temmelig tydelig som et led i den æstetiske branding af Norden. ${ }^{6}$

Det første afsnit er atypisk, fordi de medvirkende lokale ikke præsenteres ved navn eller som eksperter i de lokale madvarer, de optræder bare. Det er også atypisk, fordi der aldrig etableres egentlige narrativer om maden, den er en råvare, der tilberedes. Det forklares ikke, hvor vi er i verden, Limfjorden og Løgstør benævnes blot og vises kort på et stiliseret kort. Men afsnittet er typisk, hvad angår den let distante og kunstige underlægningsmusik og de skarpe reallyde fra knive og redskaber, når der laves mad. Lyssætningen er også ens i afsnittene, den er tydelig og lige på Claus Meyer og står ofte i modsætning til solens stilling eller belysningen af landskabet. Det kunstige lys giver sammen med musikken indtryk af en reklame- eller turistæstetik, der står i mærkelig modsætning til det minimum af information, der faktisk gives om selve stedet - og Danmark: Stedet tillægges betydning, men samtidig demonstreres det, at det ikke har den store betydning, fordi det ikke forlenes med dybde eller narration: Det gør kun smagen og smagen ligger i Claus Meyers mund.

Andre afsnit, som det om Læsø og Samsø (Afsnit 7: DR: 19.06.07), gør langt mere ud af selve kortlægningen. Claus Meyer fotograferes i den indledende sekvens ombord på et lille fly, og vi ser luftfotos af først Sams $\varnothing$, så Læsø, og får dem placeret med røde prikker på et kort over Danmark. Vi får også information om indbyggertal og turistantal, så her er turistvinklen tydeligere. Der opbygges også narrativer, der giver 'fylde' til programmet. Vi får historien om Samsøkartoflen, jordbund og dyrkningsforhold, og her er kartoffelavleren navngivet og får respekt som ekspert på sit felt. Det samme gør saltsyderen og honningavleren på Læsø, ligesom vi møder eksperten i skagenskunsten i afsnittet om Skagen. I de andre afsnit er det således tydeligere, hvad programmets intention er: At brande Danmark og dansk mad, især de madvarer, som eksporteres: kartofler, salt, fisk og Meyers egne raffinerede produkter. Så stedet forlenes med betydning, men er samtidig betydningsløst: Stedet sidder sådan set i varen, uanset hvor i verden varen befinder sig. Sted bliver til en kvalitetskategori, en slags smagsstandard, der, som vi skal se, samtidig er knyttet til de mennesker, der forarbejder varen.

Afsnittet om Norge sætter dette i relief (Afsnit 13: DR: 31.07.07). Det begynder i København, og den første tilberedning af mad sker på Oslo-færgen, hvor sejlruten vises, og der svælges i dækfotos og stemning fra broen, hvor kaptajnen bryder ud i sømandssang. Her er der fokus på en norsk eksportvare, nemlig Linjeakvavit, men ellers berømmes Norge for sin vilde (ægte) natur, som ikke findes i Danmark, og det betones, at netop denne vilde, ægte vare ikke eksporteres. Vil man have den, må man som turist klatre op i højderne på Jotunheimen og besøge en eksklusiv restaurant, der kun kan nås ad en længere vandrerute. Stedet forlenes her med en tilstedeværelsens eksotik, som demonstreres af Claus Meyer, fordi også han som seerens stedfortræder er turist her, og som ægte turist må han spørge sin guide, den norske tv-kok Arne Brimi, om vejledning og råd. Episoden demonstrerer turistens blik: Den autentiske smagsoplevelse er nok knyttet til stedet, men opskriften er samtidig tilgængelig alle steder.

Claus Meyer er som tv-kok typisk. Han er henført af sin smag, han fremstår yderst smagskompetent og belærer seerne om, hvordan man bedømmer en råvare, smager maden til og smager den til sidst. Alle afsnit slutter med et måltid, hvor Claus Meyer serverer sin mad for nogle få venner eller lokale og serverer lokal øl og snaps til. Det sociale er 
normalt madens mål, men dette mål forlades i alle episoder hastigt. Det er den forestillede socialitet, som seeren kan etablere i sin imagination om enten varen eller stedet, mere end det er den i og for sig uvedkommende sociale sammenhæng, som kameraet viser kort.

Udsagneter: Rejs til Danmark og mød udsøgte rammer - eller imiter maden derhjemme og etabler en social oplevelse, eller se bare programmet og forestil dig nydelsen, der kunne etableres. Selve programmets underholdende effekt er blandingen af det didaktiske, det rituelle og så nydelse af den sociale mulighedssituation, som programmet præsenterer. Gør det, hvis du vil! Eller nyd det i sofaen. Billederne giver i deres klare belysning mulighed for nydelsen i sig selv. Men samtidig giver programmerne mulighed for at lære og efterligne, der er altid en didaktisk indføring i råvarekvalitet, i tilberedningsmetoder og i smagssansning. Didaktikken forstyrrer ikke underholdningen, men forstærker den. Den er diskret, og den er enten ekspertbåren eller amatør-ekspertbåren. Her tales ikke ned, men til, venligt og indforstået og med ekspertise. Seeren placeres således i en potentiel ekspertrolle, som 'med-vidende' og som vidne til den smagsoplevelse, som kun kan udtrykkes ækvivalent med et mmm, altså egentlig ordløst og indadvendt.

Mad i Norden er således i sin fortællestrategi konsekvent dobbelt. Den engelske madsociolog Alan Warde (Warde, 1997) påviste i en undersøgelse af engelske madmagasiner fra 1960'erne frem til begyndelsen af 1990'erne, at madstoffet her var opbygget over en række polariteter, hvor den ene principielt udelukkede den anden: Fornyelse-Tradition var en af dem. ${ }^{7}$ I Smagen af Norden er balancen tværtimod præcis at vise begge: Traditionen er der i landskaber, fiskekuttere og traditionelle råvarer, men fornyelsen er der samtidig i moderne dyrkningsmetoder og smagsforfinelser, i ingredienssammensætningen og i tilberedningen. Det kommer næsten ekstremt til udtryk i seriens sidste episode om Nordsjælland, hvor Camilla Plum og Per Kölster i samdrægtighed med en Carlsberg-direktør taler om ikke at genfinde smagen af Norden, men om at finde en ny smag af Norden. En lignende dobbelt konstruktion er allerede antydet om selve måden at fokusere på Danmark og stederne på.

\section{Stedets betydning: Terroir og autenticitet}

Ifølge forordet til bogen Mad i Norden. Smagen af Danmark af Claus Meyer (Meyer, 2007) blev ambitionerne hos de norsk/amerikanske producenter af programserien Madi Norden, Tellus Works, først under deltagelse i det nordiske køkkensymposium på restaurant noma i foråret $2004^{8}$ stimuleret af bevidstheden om, at den planlagte tv-produktion kunne være med til at "fremme udviklingen af kvalitetsfødevarer og regionale køkkener med en klar identitet og være med til at skabe et nyt, originalt, nordisk køkken" (Meyer, 2007, p. 6). De besluttede at lægge det nordiske køkkenmanifest ${ }^{9}$ til grund for den kommende produktion, og det er sandsynligvis denne vision, som er søgt realiseret i programserien Mad i Norden.

Det nordiske køkkenmanifest er en ambitiøs hensigtserklæring underskrevet af kokke, heriblandt Claus Meyer, i Danmark, Sverige, Finland, Norge, Island, Færøerne og Grønland, som søger at spidsformulere visioner og regler for opbygning af et køkken, som man betegner som nyt nordisk. Det synes derfor oplagt at læse tv-serien Mad i Norden i direkte forlængelse af det madarbejde, som Claus Meyer har lavet i Danmark de sidste 20 år, og som gennemgående har haft råvarekvalitet og artsrigdom på programmet ${ }^{10}$, og hvor noma og Manifest for det Nye Nordiske Køkken er nogle af de seneste skud på stammen. Serien etablerer og bruger et stedsbegreb, terroir, og hævdelsen af terroir og stedets autenticitet og betydning bliver de grundlæggende elementer i den mytologisering af 
det nye nordiske køkken, som programserien producerer, og som kommer til udtryk i Meyers itale- og iscenesættelse og (delvis) i seriens billedæstetiske fremstilling. Som tvunderholdning har serien en pædagogisk attitude i forhold til at skabe kompetencer i at indskrive sig i seriens fortællinger om mad og steder. Det er det, der gør, at maden også kan nydes som medieret produkt. Der er altså ikke tale om erstatningsnydelse, men om nydelse i sig selv - en nydelse af den medierede mad.

Hvert af de 13 Mad i Norden-programmer er optaget på flere forskellige lokationer indenfor et afgrænset geografisk område, fx Sams $\varnothing$, Fyn, Skagen. I hvert program flyttes vi som seere fra et sted til et andet og stifter undervejs bekendtskab med stederne, de fødevarer, som dyrkes her, og de producenter, som lever her. Stedet er en afgørende konstruktion i denne sammenhæng - en konstruktion, som fungerer på flere planer.

I differentieringen af forskellige betydningssætninger af terroirbegrebet i programserien, som vi udfolder i det følgende, har vi ladet os inspirere af turismeforskeren Nin Wang. Han introducerer i sit arbejde en skelnen mellem forskellige former for autenticitet i turistoplevelser, fordi han gerne vil kunne sige noget om oplevelsen af autenticitet i forbindelse med turiststeder ('mig' i relation til stedet) frem for udelukkende at kunne tale om den autenticitet, som steder eller handlinger kan have, eller genstande kan tillægges. Han introducerer en tredeling: 1. Objektiv autenticitet, hvor den autentiske oplevelse afgøres ved, om det oplevede anerkendes som i sig selv autentisk. Hvis tingen er ægte, så er oplevelsen autentisk; 2 . Konstrueret autenticitet i forhold til hvilken autenticiteten afgøres ved, om fx en genstand på overbevisende måde er socialt konstrueret som autentisk; og 3. Eksistentiel autenticitet, som er de personlige og subjektive følelser, der aktiveres i selve mødet med fx et sted eller en genstand, og som opleves som autentiske, dvs. autenticiteten bliver relationel frem for knyttet til genstande an sich (Wang, 1999). I det følgende opererer vi, inspireret af Wang, dels med 1. Objektivt terroir (T1), som er en stedskonstruktion, der udelukkende implicerer understregningen af dyrkningens fysiske betingelser (jf. Wangs 1), og 2. Konstrueret terroir (T2), som dækker over stedslige legitimeringer, som overskrider det, der kan henregnes til 1 og 3. Eksistentielt terroir (T3) er stedskonstruktioner, hvor stedets materielle kvaliteter transcenderes gennem fortællinger, hvor stedet i sig selv bliver mindre vigtigt, men hvor relationen mellem mennesker og sted bliver afgørende, hvorfor denne modus af terroirbegrebet bliver refleksiv og affektiv.

Dramaturgisk er serien opbygget omkring forskellige fysiske steder, og afsnittene bærer overskrifter som "Den særlige Limfjordssmag" (Afsnit 1: DR: 08.05.07), "Fynsk forår" (Afsnit 3: DR 22.05.07), "Grønne jordbær i Gudhjem" (Afsnit 5: DR: 05.06.07). Denne opbygning indikerer, at serien formidler kendskab til råvarer og produkter, som har en stedslig tilknytning, terroir. Dette begreb må vi foretage en afklaring af. Terroir betyder i traditionel forstand "dyrkningsstedets indflydelse på råvaren: jordbundsforholdene, lyset, varmen, vinden og nedbøren" (Redzepi \& Meyer, 2006, p. 168), og har især været anvendt indenfor vinproduktion til beskrivelse af vinens og dyrkningens fysiske betingelser: "the complete natural environment in which a particular wine is produced, including factors such as the soil, topography, and climate [...] Also goût de terroir: the characteristic taste and flavour imparted to a wine by the environment in which it is produced. - ORIGIN French, from medieval Latin terratorium" (Oxford Dictionary of English). Denne udgave af terroir kan vi kalde objektiv (T1), idet den handler om, at det sted, noget dyrkes, influerer på dets smag etc. I nogle sammenhænge henviser begrebet kun til materialistiske faktorer som jordbund, klima etc., i andre medregnes også stedets traditioner for netop denne 
dyrkning, og i atter andre bliver betydningen mytologiseret og spiritualiseret gennem påstande om stedets sjæl etc. (T2 og T3).

Seriens grundlæggende greb er at tage os, seerne, ud i forskellige landskaber, til forskellige egne, som qua deres særlige ikke bare fysiske egenskaber, men også qua deres aura, hævdes at have frembragt en eller flere enestående råvarer, som Meyer anpriser, evt. interviewer nogen omkring (fx en producent eller en "ildsjæl"), for så at tilberede et måltid i sit mobile udendørskøkken, hvori denne råvare har en fremtrædende plads. I denne sammenhæng er stedet - i det mindste verbalt og dramaturgisk - iscenesat som den aktuelle råvares "hjem" og egentlige producent: Det er næsten naturen eller jorden selv, der har produceret denne mad (jf. Lammefjordens gulerødder, Afsnit 8: DR: 26.06.07), og tilberedningen on location er en autentificering og legitimering af dette. Men hvis denne egentlige betydning af terroirbegrebet i sin materialistiske form (T1) skulle kunne betragtes som den eneste i serien, ville det kræve, at serien konsekvent fremhævede stedsspecifikke fødevarer. Det ville implicere en hævdelse af, at (grønne) jordbær er bedst, når jordbærrene er dyrket i Gudhjem eller omegn, og at de asparges eller rabarber, som er en del af tilbehøret i afsnittet om det fynske forår, er dyrket i fynsk muld, men dette er ingenlunde tilfældet. Samtidig sker der i flere af afsnittene en eksplicit fremhævelse af, at fødevareproduktion et givent sted faktisk er af nyere dato. Dette gælder fx gulerodsdyrkningen i Lammefjorden (Afsnit 8: DR: 26.06.07) og humledyrkningen til Kølsters ølproduktion (Afsnit 12: DR: 24.07.07). Her træder et relationelt terroirbegreb i stedet (T3).

For yderligere at kunne udvide vores begrebslige forståelse til også at kunne omfatte en mindre materialistisk opfattelse af terroir kan det være nyttigt at introducere begrebet mytologisering. Ifølge religionsteoretikeren Russell T. McCutcheon skal myten ikke ses som en historie med et særligt indhold, men som en social strategi, et legitimerende fortælleredskab, eller med Roland Barthes' ord kan vi sige, at "[m]yten defineres ikke ved det, den er budskab om, men ved den måde, hvorpå den fremfører budskabet" (Barthes, 1969, p. 143). Myter præsenteres dermed som noget, "vi her er enige om" (McCutcheon, 2000, p. 204). Mytologisering er altså at få bestemte verdenssyn til at fremstå allestedsnærværende og absolutte (McCutcheon, 2000, p. 205), at italesætte dem en gang for alle, så udsagnet ikke kan drages i tvivl, og så vi ikke behøver tale om dem igen (selvfølgeliggørelse). Mestringen af denne form for italesættelse implicerer en mestring af at kunne forbinde sig intellektuelt og følelsesmæssigt til det, der tales om, og at være med til at etablere, fastholde og videreføre det som væsentligt. Det, der mytologiseres, placeres dermed også indenfor rammerne af, hvad der i en given kulturel tradition opfattes som acceptabel kultur eller kulturel genkendelighed. ${ }^{11}$ Mytologisering er således en social størrelse. Mytologisering er en fortælling, en fortælleproces, der naturaliserer udsagn, som ofte er af emotionel, affektiv art, og hvis udsagn er basale og inderligt væsentlige for den eller de implicerede.

Den basale mytologisering i Mad i Norden er den, der foregår omkring terroirdimensionen, og den er en grundmytologisk figur i hele etableringen af en ny nordisk køkkenidentitet, hvor netop hævdelsen af stedets indflydelse på råvarerne er helt grundlæggende, og hvor mennesket basalt set er fraværende: "Det er terroiret der gør dem - i helt konkret betydning - enestående i verden [...] Terroir er hele stedets sjæl det, som stort set er upåvirket af tiden. Mennesket derimod er en flygtig biting. Terroir består, mennesker forgår" (Redzepi \& Meyer, 2006, p. 168). Det er stedets unikke karakter af medbetydende aura for råvarekvaliteten, som skal bære denne vision, og i Mad $i$ 
Norden formidles madens eller råvarernes terroirdimension gennem en dramaturgi og italesættelse samtidig med, at serien etablerer et meget rummeligt terroirbegreb, som inviterer seerne indenfor til individuelle indskrivninger og mytologiseringer. Brugeren af serien opfordres således til selv at foretage mytologiseringer, som forbinder ham eller hende til stedet.

En væsentlig del af terroirbegrebets legitimitet findes nemlig i den del, der ikke er omfattet af betydningen dyrkningsstedets indflydelse, men derimod netop som den særlige aura, som Norden og Danmark hævdes at have, og som er mytologisk basal. Denne kan findes i den autenticitet, som terroirbegrebet i Meyers mere spirituelle udgave påberåber sig. Terroir i denne sammenhæng bliver til en konstruktion af autenticitet, hvor det hævdes, at stedet har en aura, en sjæl, en kraft, som besjæler den mad, der dyrkes i området, og forsyner den med en ganske særlig smag. Altså terroir i en spiritualiseret udgave (T3).

\section{Stedsspecificitet og globalisering}

Når vi ovenfor peger på, at stedet (terroir) hos Meyer findes i 3 former, så er dette et forsøg på at systematisere den kompleksitet, som det involverede stedsbegreb rummer. Stedet er ikke kun et fysisk sted. Det fungerer i den aktuelle programserie på mange niveauer, som ikke kun handler om at bruge banale fortællinger om stedet og skamride nogle få historiske traditioner for fødevareproduktion i Danmark og blæse disse op til store visioner om STEDET for at lokke turister til. De stedsudsagn og stedsæstetiske iscenesættelser, serien rummer, er tilsvarende komplekse. Ofte er der tale om flere typer af stedskonstruktioner på én gang.

Denne kompleksitet tydeliggøres $\mathrm{fx}$ i afsnittet med titlen "Humleeventyret" (Afsnit 12: DR: 24.07.07), hvor Meyer blandt andet besøger Fuglebjerggård, hvor makkerparret Camilla Plum og Per Kølster har opbygget et økologisk produktions- og kursussted. Kølster producerer $ø l$ blandt andet af humle produceret på Danmarks eneste humlemark og reflekterer over sin produktion således:

[...] man kan da håbe, altså fordi den type byg, vi dyrker i Danmark og har gjort det i vores historie i mange mange hundrede år, det er faktisk en byg, som var almindeligt dyrket i 1960'erne i Danmark, den er altså mere end 40 år gammel [sic!], så har den en anden måde at vokse på. I princippet vokser den langsommere, den er ikke lige så potent som de moderne sorter. Den er mere sådan koncentreret, og det er jeg ret overbevist om, at det er noget, der kan smages i øllet, men grundlæggende vil jeg sige, at det er sjovest at have noget, der er noget særligt, altså at få sat et eller andet præg på det her, som er MIT, eller i bedste fald kunne man måske også sige VORES, altså at det havde en dansk smag (Afsnit 12: DR: 24.07.08).

Kølsters udsagn henviser altså til terroiret som dyrkningsstedets indflydelse på varen (T1), endskønt der også er andet i spil, idet han hævder, at den mængde år, noget har været dyrket i, har indflydelse på smag og vokseegenskaber (T2). Og at det også handler om, hvordan han som producent kan indskrive sig selv i produktets tilblivelse og dermed skabe både sig selv og sit øl som unikt og autentisk (T3), og dermed er alle terroirbegrebets tre betydninger ude at gå. Dette ene afsnit (12) bliver således en fortættet udgave af hele 
seriens terroir-kompleksitet. Da dette afsnit er det sidste program om en dansk lokalitet, får det en slags opsummerende karakter.

Dennelæsning bliver yderligere tydelig, hvis vi tilføjer Camilla Plums optræden i samme program. Plum og Meyer besøger blandt andet koldhusene (= uopvarmede drivhuse), hvor der dyrkes tomater, og Plums understregning af de forskellige tomatsorters oprindelse: Denne tomat er en kinesisk vildtomat, og denne er russisk ("efter Murens fald har vi fået alt muligt, vi ikke har set i 70 år"), og denne er italiensk, samt hendes redegørelse for sin dyrkning af majs (som er en oprindelig indiansk - og dermed ikke nordisk - afgrøde) gør det nødvendigt at reflektere over stedsspecificitetens betydning. Plums udsagn transcenderer terroirbegrebet som produktionsstedets materielle indflydelse (T1) og for så vidt også den socialt konstruerede (T2) og peger på en omsorgsdimension i dyrkningsarbejdet, som understreger individets og relationens betydning (T3): "Disse sorter er resultatet af menneskers arbejde i tusindvis af år, ikke bare i Sydamerika, men også efter at de kom her til... til sidst ender man med en vildt stor variation [...]" (Afsnit 12: DR: 24.07.08).

Programseriens stedsspecifikke strategier handler således både om relationering og glokalisering. Relationering, fordi strategien handler om at forbinde sig affektivt til steder gennem mytologiserende fortællinger, der forsyner et givent (tilfældigt) sted med en række kvaliteter, der i samme bevægelse etableres som attråværdige og naturaliserede. At værdsætte det nordiske, det danske, det fynske etc. er en lokaliseringsstrategi eller, med globaliseringsteoretikeren Roland Robertson (Robertson, 1995), en glokaliseringsstrategi, som ikke handler om at fornægte globaliseringen, men om at bidrage til den qua lokale strategier, som netop viser, at vi alle ER del af globaliseringens processer. Terroir som begreb handler således om, at ethvert sted er unikt, og at det enkelte menneske trods globalisering spiller en rolle i forædling og varsomhed i dyrkningsarbejdet. Serien indskriver sig derfor i en mangfoldigheds-, samarbejds- og rummelighedstænkning, som kun kan være global. Når Plum afslutningsvist spørges, hvad det betyder, at dyrkningen er økologisk, svarer hun: "I det store perspektiv vil jeg sige, at så skaber det KUN mening, hvis det er økologisk. Det kan man blive ved med. Alt det andet, det kan man ikke blive ved med. Det andet handler ikke om fremtid - det handler kun om nu og her" (Afsnit 12: DR: 24.07.08). Plum understreger altså, at det at arbejde lokalt har globale konsekvenser.

Det menneske- og verdenssyn, som serien formidler, drejer sig således om rummelighed, global ansvarlighed, kompleksitet, og at vi må respondere på verden med multiple strategier, i hvilke nydelse og ansvarlighed fylder lige meget. Når de involverede producenter og øvrige aktører italesætter stedet som særligt (T3), så har disse udsagn i serien samtidig karakter af didaktiske læresætninger, som stiller sig til rådighed for en imitativ praksis hos os som seere, således at vi gennem serien lærer os selv at foretage de mytologiserende indskrivninger i konkrete steder. Det er denne indskrivningsmulighed, som serien sælger. Som underholdningsprodukt sælger den os nydelsen ved medieret mad, hvis mytologiseringsprocessen lykkes. Men dens ærinde er også at brande Danmark og Norden. Danmark og Norden. Hvis det første niveau lykkes, er der åbent for det andet.

\section{Outro}

Gennem hele programserien er Danmark repræsenteret som "det skønne Danmark" i form af smukke, men stereotype billeder. Seriens billedside, endskønt den i overfladisk forstand er æstetisk smuk, er samtidig at ligne med en gammel turistfilm, man engang har set, og hvor øjet får det, man forventer, af Danmark. Hvor billederne, dramaturgien og aktørerne repræsenterer Danmark indenfor rejseprogrammets grundlæggende matricer. 
Som medie- og turismeforsker Anne Marit Waade har peget på, så er tendensen i de nye rejseprogrammer - i modsætning til de klassiske etnografiske og dokumentariske film, hvor oplysning og formidling er en grundmatrice for iscenesættelsen af det fremmede netop, at de er "fængende underholdning" (Waade, 2004, p. 56). Mad i Norden kan ses som placebranding af Danmark gennem brugen af et terroirbegreb, der både er helt specifikt og samtidig helt åbent. Maden bliver således et redskab til at skabe appetit på enten at rejse til de pågældende steder eller købe de pågældende madvarer eller bare til at se serien.

Branding er seriens grundlæggende betingelse, idet den er finansieret qua interessenters sponsorater. Dette er fx tydeligt i afsnittet i afsnittet "Humleventyret" (Afsnit 12: DR: 24.07.07), hvor Meyer i forlængelse af besøget på Fuglebjerggård besøger Jens Eiken, som er en af de unge brygmestre på bryggeriet Carlsbergs Jacobsen-koncept, som klart redegør for, hvordan man i Norden har startet et samarbejde blandt mikrobryggerier og bryggerier med bevidsthed omkring det stærke identitetsproducerende element i oplevelsesorienteringens brandingstrategier:

Der sker jo meget i samfundet og herinde i Carlsberg, hvor vi tror på, at der er en unik mulighed for at lave noget nyt, en ny smag [...]. Lad os se indad og prøve noget nyt. Hvad er det nordiske for noget, kan vi finde en nordisk smag. Vi mangler vores identitet heroppe. Hvorfor ikke se indad i stedet for at lave kopier hele tiden. Jamen lad os se indad og prøve noget nyt.

Carlsberg er bevidst omkring de muligheder for fortællingsproduktion, som terroirdimensionen rummer, og som i en oplevelsesorienteret kultur rummer et stort spektrum af indskrivnings- og mytologiseringsmuligheder både på brandniveau og for enkeltindivider. Serien har, som vi har argumenteret for, samme bevidsthed.

Stedet er, som vi har vist, både et specifikt sted og et al-sted, tiden er på samme måde uden for en specificeret tid. De 13 episoder forløber fra april til september - altså en form for feriesæson. Den krop, som er hovedfiguren i serien, er tilsvarende en arbejdsfri, men bevægelig, energisk og arbejdende krop - ved et bord, på cykel, i marken osv. Claus Meyer laver mad, men han gør det langsomt, pædagogisk og nydende uden kun at have måltidet som mål. Den nydelse, serien især demonstrerer, er altså en nydelse af processen frem mod måltidet. Serien er en branding af Meyer, maden og Danmark, og derfor er serien ikke kun en madserie, men også en rejseserie, der gerne vil have den lokale og den rejsende i tale. Sponsoreret som den slags ofte er.

Denne dobbelte henvendelsesform er tv velegnet til, fordi kameraet i de levende billeder uafbrudt kan skifte fokus, som demonstreret i næranalyserne. Hverken kogebogen eller netsiden, der knytter sig til udsendelsesrækken, kan det samme, og de fokuserer derfor klogeligt på maden, Meyer og har så enkelte naturbilleder. De er begge mere koncentrerede om opskrifterne og produkterne. Tv har således en fordel, der måske bliver særlig stor i sammenhæng med de trykte og digitale medier.

En serie som Mad i Norden med dens udtrykkelige italesættelse af madens terroir og med dens mytologisering af mad-stedet er et fint eksempel på, hvordan medialiseringen tilbyder brugerne små mikrooplevelser i hverdagen, som er et (medie)forbrug i sig selv og som samtidig giver mulighed for at forestille sig forbruget efter medieforbruget, nemlig forbruget af mad (Jantzen \& Rasmussen, 2007, p. 41-43). Esteticeringen af de hverdagslige sociale og selvrefleksive relationer til design (LeCreuset, Royal Copenhagen, Eva Trio), til steder i Danmark (Limfjorden, Samsø, Læsø, Nordsjælland) og til valget 
af råvarer (muslinger, salt, kartofler og øl) kan støtte brugernes forestillingsarbejde og dermed øge og gøre nydelsen dobbelt: Nydelsen af tv-serien, nydelsen ved det mentale forestillingsarbejde - og nydelsen for dem, der realiserer nogle af deres forestillinger. Serien er således didaktisk på flere niveauer: Den viser valg af sted, af vare, af opskrift. I den visning demonstrerer den også, hvilke nydelses- og smagspotentialer stedet, varen og forarbejdningen har. Selve forbruget af produktet derimod fader ud i en hastig efterklang. Når kameraet i afsnittet om Skagen (Afsnit 2: DR: 15.05.07) kærtegner rødspætten, træder kameraet i stedet for vores tunge, ligesom kameraet generelt faciliterer den iscenesættelse af seerens blik, som gør, at praktiske og medierede erfaringer kan forbindes til hinanden og dermed kvalificere denne form for erfaring.

Den autenticitet, som terroir-bevidsthed forlener maden og stedet med, kan således sekunderes af den autenticitet, som følelsen af indre nydelse under medieforbruget afstedkommer. Det er god underholdning.

\section{Referencer:}

Andreasen, R.W. (2006). Smag Bedre!. Århus: Speciale fra Aarhus Universitet, IMV.

Barthes, R. (1969). Mytologier. København: Rhodos.

Barthes, R. (1979 (1969)). Towards a Psycho-Sociology of Contemporary Food Consumption. In Forster \& Ranum (Eds.), Food and Drink in History (pp. 166-173). Baltimore: John Hopkins University Press.

Bonner, F. (2005). Whose Lifestyle is it Anyway? In Bell \& Hollows (Eds.), Ordinary Lifestyle. London: Open University Press.

Jantzen, C. \& Østergaard, P. (2007). Nyd det! Nyd det! Den moderne hedonisme og dens mentalitetshistoriske forudsætninger. In Jantzen \& Rasmussen (Eds.), Oplevelsesøkonomi (pp. 83-114). Aalborg: Aalborg Universitetsforlag.

Jantzen, C. \& Rasmussen, T.A. (2007). Forord til Oplevelsesøkonomi (pp. 21-50). Aalborg: Aalborg Universitetsforlag.

Klitgaard Povlsen, K. (1986). Blikfang. Aalborg: Aalborg Universitetscenter.

Klitgaard Povlsen, K. (1996). Skrifter til tiden, Den illustrerede virkelighed (pp. 270-278). In K.B. Jensen (red.), Dansk mediehistorie 3. København: Samleren.

Klitgaard Povlsen, K. (2007). Smag, livsstil, køn og madmagasiner. MedieKultur 42/43, 46-53.

Luckman, T. (1990). Shrinking Transcendence, Expanding Religion. In Sociological Analysis, 50(2), 127-138.

Lundby, F.S. \& Pedersen, L. (2007). Smagstid - Ny nordisk mad i sæson, Gylling: Anblik.

McCutcheon, R. (2000). Myth. In Braun \& McCutcheon (Eds.), Guide to the Study of Religion (pp. 190-208). Cassell.

Meyer, C. (2007). Mad i Norden. Smagen af Danmark, Gylling: Aschehoug.

Miller, T. (2007). Cultural Citizenship. Philadelphia: Temple University Press

Redzepi, R. \& Meyer, C. (2006). Noma - Nordisk Mad. København: Politikens Forlag.

Robertson, R. (1995): Global Modernities. London: Sage

Waade, A.M. (2004). Rejseholdets Danmarksbilleder. Om stedets æstetik, kameraets kartografiske turistblik og rejsens forvandling. In Passepartout. Skrifter for Kulturhistorie 24(12), 55-72.

Wang, N. (1999). Rethinking authenticity in Tourism experience. In Annals of Tourism research, 26 (2), 349-370.

Warde, A. (1997). Consumption, Food, and Taste. London: Sage.

\section{Noter:}

1 Claus Meyer lancerer serien under samme titel som kogebogen, nemlig Smag på Danmark, men producenternes titel på denne del af en større nordisk serie er Mad i Norden, som også optræder som titel i de enkelte danske episoder. Vi bruger herefter titlen Mad i Norden også for de danske episoder.

2 Henvisning i det følgende: Afsnitnummer, fx "afsnit 10", herefter "DR" og dato for første sending, fx "10.07.07": Afsnit 10: DR: 10.07.07. 
3 En oversigt bare på egentlige madprogrammer viser ret stigende kurver på de dansksprogede tvkanaler i en tid, hvor udbuddet af tv i det hele taget stiger stejlt. Især siden 2002 år er madprogrammer blevet populære. Der er tale om en stigning fra ca. 50 sendetimer til ca. 350 sendetimer pr. år. Dertil kommer de mange morgen- og aften-magasinprogrammer etc med madindslag, børne-tv. Mindre kanaler som TV 2 Charlie og DR2 bruger op mod 10 procent af sendetiden på madprogrammer efter 2004. 4 Oplyst af Birdie Bjerregaard, chefredaktionen i DR .

5 I 2008 udkom der seks deciderede madmånedsmagasiner i Danmark (Spis, Mad!, Gastro, Mad og Venner, Smag og Behag, Mad og Bolig) samt et utal af ugeblade og magasiner med en stor del madstof (mange gratismagasiner heriblandt), på nettet er der en række store, ganske heterogene opskriftsamlinger i mere eller mindre tæt alliance med mad fra andre medier (fx på www.dr.dk) eller med kommercielle aktører ( $\mathrm{fx}$ www.arla.dk). I de seneste år er der udkommet et større antal kogebøger, skrevet af mediekendte kokke med fokus på dansk eller skandinavisk mad, bl.a.:

Thomas Herman 2007: Brændende kærlighed, Aalborg: Klematis; Bo og Lisbeth Jakobsen 2007: Dansk mad derhjemme. København: Olivia; Jensen og Røjel 2007: Dansk Gastronomi. København: Gyldendal; Claus Meyer 2007: Mad i Norden: Smagen af Danmark. Gylling: Aschehoug; Lundby og Pedersen 2007: Smagstid, ny nordisk mad i sæson. Gylling: Anblik; Tina Nordström 2005: Tinas svenske madrejse. København: Aschehoug; Camilla Plum 2004: Umoderne mad. København: Politiken; Camilla Plum 2001: Mors Mad. København: Politiken; Redzepi og Meyer 2006: NOMA Nordisk mad. København: Politiken; Nanna Simonsen 2007 (2003): Smag på Danmark. København: Gyldendal.

6 Ganske anderledes ser det ud i de svenske afsnit af serien, sendt på SVT 2006, hvor de firmaer, der optræder med produkter, er nævnt som sponsorer i selve afsnittenes begyndelse - og på seriens hjemmeside www.Scandcook.com er sponsorfirmaerne omhyggeligt listet med deres logoer.

7 Den modsætningsopbygning findes ikke tilsvarende i moderne danske madmagasiner, hvor kompromisset mellem modsætningerne er mere fremtrædende (Andreasen 2006, Klitgaard Povlsen 2007).

8 Restaurant noma, Nordatlantens Brygge, Strandgade 93, København. Grundlagt af bl.a. Claus Meyer, i 2007 placeret som nr. 15 i klassificeringen The World's 50 Best Restaurants og indehaver af 2 michelinstjerner. Om noma, Meyers andel i denne samt dens grundvisioner, se Redzepi \& Meyer, 2006.

9 Se de 10 dogmeregler Manifest for det Nye Nordiske Køkken i Redzepi \& Meyer, 2006:175.

10 Se www.clausmeyer.dk for en oversigt over Meyers entrepreneurielle, gastronomiske virke.

11 Begrebet kulturel genkendelighed er lånt hos Dorte Marie Søndergaard (Søndergaard 2000). 